Pesq. Vet. Bras. 30(1):57-62, janeiro 2010

\title{
Immunogenicity of an inactivated bovine herpesvirus type 5 strain defective in thymidine kinase and glycoprotein $\mathrm{E}^{1}$
}

\author{
Mário Celso S. Brum², Luizinho Caron ${ }^{3}$, Shafiqul I. Chowdhury ${ }^{4}$, Rudi Weiblen ${ }^{5}$ \\ and Eduardo Furtado Flores ${ }^{*}$
}

\begin{abstract}
Brum M.C.S., Caron L., Chowdhury S.I., Weiblen R. \& Flores E.F. 2010. Immunogenicity of an inactivated bovine herpesvirus type 5 strain defective in thymidine kinase and glycoprotein E. Pesquisa Veterinária Brasileira 30(1):57-62. Setor de Virologia, Departamento de Medicina Veterinária Preventiva, Centro de Ciências Rurais, Universidade Federal de Santa Maria, Av. Roraima 1000, Camobi, Santa Maria, RS 97105-900, Brazil. E-mail: eduardofurtadoflores@ gmail.com

The immunogenicity of an inactivated, experimental vaccine based on a bovine herpesvirus type 5 strain defective in thymidine kinase and glycoprotein $\mathrm{E}$ (BoHV-5 gE/ $\mathrm{TK} \Delta$ ) was evaluated in cattle and the results were compared with a vaccine containing the parental BoHV-5 strain (SV507/99). To formulate the vaccines, each virus (wildtype SV507/99 and BoHV-5 gE/TK $\Delta$ ) was multiplied in cell culture and inactivated with binary ethyleneimine $(\mathrm{BEI})$. Each vaccine dose contained approximately of $10^{7.5} \mathrm{TCID}_{50}$ of inactivated virus mixed with an oil-based adjuvant (46:54). Forty calves, 6 to 9-monthsold, were allocated into two groups of 20 animals each and vaccinated twice (days 0 and $22 \mathrm{pv}$ ) by the subcutaneous route with either vaccine. Serum samples collected at day 0 and at different intervals after vaccination were tested for virus neutralizing (VN) antibodies against the parental virus and against heterologous BoHV-5 and BoHV-1 isolates. The VN assays demonstrated seroconversion to the respective homologous viruses in all vaccinated animals after the second vaccine dose (mean titers of 17.5 for the wildtype vaccine; 24.1 for the recombinant virus). All animals remained reagents up to day 116 $\mathrm{pv}$, yet showing a gradual reduction in VN titers. Animals from both vaccine groups reacted in similar VN titers to different BoHV-1 and BoHV-5 isolates, yet the magnitude of serological response of both groups was higher against BoHV-5 field isolates. Calves vaccinated with the recombinant virus did not develop antibodies to $\mathrm{gE}$ as verified by negative results in a gE-specific ELISA, what would allow serological differentiation from naturally infected animals. Taken together, these results indicate that inactivated antigens of BoHV-5 gE/TK recombinant virus induced an adequate serological response against BoHV-5 and BoHV-1 and thus can be used as an alternative, differential vaccine candidate.
\end{abstract}

INDEX TERMS: Vaccines, DIVA, differential vaccine, glycoprotein E, recombinant vaccine.

\footnotetext{
${ }^{1}$ Received on July 7, 2009.

Accepted for publication on August 24, 2009.

2 Doctoral student, Programa de Pós-Graduação em Medicina Veterinária, Centro de Ciências Rurais (CCS), Universidade Federal de Santa Maria (UFSM), Av. Roraima 1000, Camobi, Santa Maria, RS 97105900, Brazil.

${ }^{3}$ Embrapa Suínos e Aves, BR 153, Km 110, Caixa Postal 21, Concórdia, SC 89700-000, Brasil.

${ }^{4}$ Department of Pathobiological Sciences, School of Veterinary Medicine, Louisiana State University, Baton Rouge, LA, USA.

${ }^{5}$ Setor de Virologia, Departamento de Medicina Veterinária Preventiva e Departamento de Microbiologia e Parasitologia, CCS, UFSM, Av. Roraima 1000, Camobi, Santa Maria, RS 97105-900, Brazil. "Corresponding author: eduardofurtadoflores@gmail.com
}

RESUMO.- [Imunogenicidade de uma cepa inativada do herpesvírus bovino tipo 5 defectiva na timidina quinase e glicoproteína E.] A imunogenicidade de vacina experimental inativada, produzida com uma cepa do herpesvírus bovino tipo 5 defectiva nos genes da timidina quinase e glicoproteína $\mathrm{E}$ (BoHV-5 gE/TK $\Delta$ ) foi avaliada em bovinos e o resultado foi comparado com a resposta induzida pela cepa parental do BoHV-5 (SV507/99). Para a formulação da vacina, cultivos de células infectados com cada um dos vírus (SV507/99 ou BoHV-5 gE/TK $\Delta$ ) foram inativados com etilenamina binária. Cada dose de vacina continha aproximadamente $10^{7,5} \mathrm{TCID}_{50}$ de um dos vírus 
inativados emulsionado em adjuvante oleoso (46:54). Quarenta bezerros de raças cruzadas, com idade entre seis a nove meses, foram alocados em dois grupos de 20 animais cada e vacinados duas vezes (dia 0 e 22 pv) pela via subcutânea com uma das vacinas. Amostras de soro foram coletadas no dia 0 e a vários intervalos após vacinação para a pesquisa de anticorpos neutralizantes frente ao vírus homólogo ou frente a isolados de BoHV-5 e BoHV-1. Os testes de soroneutralização (SN) demonstraram que todos os animais soroconverteram após a segunda dose da vacina (títulos médios de 17,5 para o grupo SV507/99; 24,1 para o grupo BoHV-5 gE/TK $\Delta$ ). Todos os animais mantiveram níveis de anticorpos neutralizantes até o dia $116 \mathrm{pv}$, no entanto foi observada uma redução gradual no títulos. A sorologia cruzada com amostras heterólogas do BoHV-5 e BoHV-1 indicou que ambos os grupos vacinais reagiram em níveis similares frente ao mesmo vírus, no entanto a magnitude da resposta sorológica foi maior frente a amostras de BoHV-5. Os animais vacinados com a cepa recombinante não desenvolveram anticorpos contra a gE detectáveis por um ELISA específico, o que permitiria a sua diferenciação sorológica de animais infectados naturalmente. Esses resultados demonstram que a vacina contendo antígenos inativados do vírus recombinante BoHV-5 gE/TK $\Delta$ induziu resposta sorológica em níveis satisfatórios, constituindo-se, assim, em alternativa a cepa vacinal diferencial.

TERMOS DE INDEXAÇÃO: Vacinas, vacina diferencial, DIVA, glicoproteína $\mathrm{E}$, vírus recombinante.

\section{INTRODUCTION}

Bovine herpesvirus type 5 (BoHV-5) is the agent of necrotizing meningoencephalitis in cattle and is closely related to bovine herpesvirus type 1 (BoHV-1), the agent of infectious bovine rhinotracheitis (IBR), vulvovaginitis/balanopostitis (IPV/IBP) and abortions (Engels \& Ackermann 1996). BoHV-5 and -1 are widespread among South American cattle and cause important losses to the livestock industry (Silva et al. 2007b, Suarez-Heinlein et al. 1993). Although BoHV-5 infection has been described in other continents, it seems to be more prevalent in South American countries like Argentina and Brazil (Silva et al. 2007b).

BoHV-5 is an enveloped virus, containing a linear double stranded DNA molecule as genome (approximately 138kb in length) and belongs to the subfamily Alphaherpesvirinae, genus Varicellovirus (Roizman et al. 1992, Delhon et al. 2003). The viral genome encodes around 70 polypeptides, which include structural proteins, enzymes, regulatory proteins and glycoproteins (usually present in the envelope) (Delhon et al. 2003). Following primary infection, the virus establishes lifelong latency in neurons of the trigeminal ganglia (TG) or central nervous system (CNS) (Vogel et al. 2003). Latently infected animals are the main reservoirs of infection in nature, from which the virus can be periodically reactivated and transmitted to susceptible animals (Engels \& Ackermann 1996, Vogel et al. 2003).
Vaccination represents an efficient strategy to control bovine herpesvirus infections in the field (van Oirschot 1999, Ackermann \& Engels 2006). The main goal of vaccination is to prevent or reduce the severity of clinical disease and reduce/prevent virus shedding and transmission (van Oirschot 1999, Ackermann \& Engels 2006). Nonetheless, prevention of the establishment of latency by the infecting (challenge) virus has not been achieved so far by BoHV-1 vaccines (van Drunen Littel van den Hurk 2007).

Most vaccines available in South America are based on conventional inactivated BoHV-1 strains and, at least one contains a temperature-sensitive, modified live virus (MLV) (Silva et al. 2007a). Based on the antigenic similarity and serological cross-reactivity between BoHV1 and -5 , it has been postulated that vaccines containing either virus could be of value to control infection by the homologous and also by the heterologous virus (Bratanich et al. 1991, Cascio et al. 1999, Del Medico Zajac et al. 2006, Silva et al. 2006). Nonetheless, an important restriction for the use of conventional vaccines is the impossibility of differentiation between vaccinated and naturally infected (latently infected) animals (van Oirschot 1999).

Advances in molecular virology and immunology have led to the development of differential vaccines (DIVA), which are based on the capacity of the vaccine to induce a serological immune response that can be differentiated from the response induced by infection with wildtype virus (van Oirschot 1999). The association of DIVA vaccines with a differential serological test has been widely used to control herpesvirus infections, like pseudorabies virus (PRV) and BoHV-1 in several countries (van Oirschot 1999, Ackermann \& Engels 2006). In the case of BoHV1 , several DIVA vaccines are based on subunits (usually recombinant proteins) or gene-deleted virus strains (van Drunen Littel van den Hurk 2007). DIVA vaccines based on gene-deleted virus can be designed either as inactivated or live virus (van Drunen Littel van den Hurk 2007). In the case of live virus, besides the deletion of the marker gene (usually the glycorpotein $\mathrm{gE}$ or $\mathrm{gC}$ ), it may be necessary to associate a deletion of some gene involved in virulence, like thymidine kinase (TK) (Flores et al. 1993, Kaashoek et al. 1996). Several BoHV-1 genedeleted viruses have been constructed and some have been used in control/eradication programs BoHV-1 infection in Europe and North America (Kaashoek et al. 1995, Strube et al. 1996). Gene-deleted BoHV-1 and -5 Brazilian isolates have been developed and are under testing for a future use in vaccine formulations (Franco et al. 2002, 2007, Brum et al. 2009).

The immunogenicity of a vaccine formulation containing inactivated antigens of a recombinant Brazilian BoHV-5 isolate deleted in $\mathrm{gE}$ and TK genes was tested in cattle. Immunogenicity was evaluated by testing post-immunization sera collected at different intervals for virus-neutralizing (VN) antibodies against the homologous (BoHV-5) and heterologous viruses (BoHV-1 and BoHV-5 isolates). 


\section{MATERIALS AND METHODS}

\section{Virus strains and cells}

A recombinant BoHV-5 virus containing a double deletion in $\mathrm{gE}$ and TK genes (BoHV-5 gE/TK $\Delta$ ), using as background the Brazilian strain SV507/99 has been constructed and characterized in vitro (Brum et al. 2009). Both viruses used in this study (wildtype and the double deletion mutant) were propagated in CRIB cells (a MDBK-derived cell line, ATCC - CRL 11883) (Flores \& Donis 1995) maintained in MEM minimum essential medium $^{6}$ (MEM), supplemented with $10 \%$ inactivated fetal bovine serum $^{7}, 100 \mathrm{U} / \mathrm{mL}$ of penicillin ${ }^{6} 100 \mu \mathrm{g} / \mathrm{mL}$ of streptomycin ${ }^{6}$. The reference strain of BoHV-1 Cooper was obtained with Dr. Fernando A. Osorio (Center for Virology, UNL, Nebraska, USA). The field isolates used in cross-neutralization assays (BoHV-1: SV56/90, EVI123 and SV371/05 and BoHV-5: EVI88, SV136/ 88 and EVI340) have been isolated in Brazil and were previously characterized (Silva et al. 2007b).

\section{Binary ethyleneimine (BEI) inactivation and vaccine formulation}

BoHV-5 gE/TK $\Delta$ and SV507/99 were grown in T-150 flasks $\left(150 \mathrm{~cm}^{2}\right)$ containing monolayers of CRIB cells. When the cytophatic effect (CPE) reached around $90 \%$ of the monolayers, cells were scrapped off the flasks and the whole cell-virus-supernatant mixture was inactivated for vaccine production. Before virus inactivation, infectivity was determined by limiting dilution and virus titers were calculated by Reed \& Munch method and expressed as median tissue culture infection dose per mililiter $\left(\mathrm{TCID}_{50} / \mathrm{mL}\right)$. Inactivation was performed essentially as described by Bahneman (1976) with $\mathrm{BEI}(1 \mathrm{mM})$ for at least $12 \mathrm{~h}$ at $37^{\circ} \mathrm{C}$ under constant agitation. BEl was obtained after cyclization of 2-bromoethylamine hydrobromide (BEA) with $\mathrm{NaOH}(100 \mathrm{mM})$ at $37^{\circ} \mathrm{C}$ for 1 hour. Residual BEI was inactivated by addition of $1 \%$ of sodium thiosulphate solution (1M) and finally $0.01 \%$ of thimerosal was added as a preservative. Inactivated viral suspensions were kept at $4^{\circ} \mathrm{C}$ until vaccine preparation. To detect residual virus, samples from inactivated virus before adding sodium thiosulphate were collected and inoculated into preformed monolayers of CRIB cells and production of CPE was monitored thereafter.

The vaccine was prepared in water-in-oil-in-water emulsions ${ }^{8}$ containing approximately $10^{7.5} \mathrm{TCID}_{50}$ of either virus per dose. The volume of the dose was adjusted to $3 \mathrm{~mL}$ and was composed by $46 \%$ antigen and $54 \%$ of adjuvant. The inactivated virus suspension was slowly mixed with adjuvant under constant agitation at room temperature. The final mixture was maintained in sterile recipient at $4^{\circ} \mathrm{C}$. The sterility of the vaccine formulation was confirmed by the absence of bacterial growth in blood agar and LB broth (Luria-Bertani broth) after $48 \mathrm{~h}$ of inoculation.

\section{Vaccination and sample collection}

Forty mixed breed, aged between 6 to 9 months, BoHV-1 and -5 seronegative calves were used. The animals were randomly separated in two groups of 20 calves each and vaccinated by the subcutaneous route in the right shoulder with either vaccine formulation on day zero $(0 \mathrm{dpv})$. A second vaccine dose was administered at day 22 post-vaccination (pv). Serum samples were collected at days $0,22,56,78$ and $116 \mathrm{dpv}$, heat inactivated at $56^{\circ} \mathrm{C}$ for $30 \mathrm{~min}$ and stored at $-20^{\circ} \mathrm{C}$ until testing.

\section{Serology}

Virus neutralizing assays - Virus-neutralizing (VN) tests were performed according to routine procedures (Lovato et al. 2003).
Briefly, serial two-fold dilutions of sera (starting at 1:2) were incubated with a constant amount of virus (approximately 100 $\mathrm{TCID}_{50}$ ) for $1 \mathrm{~h}$ at $37^{\circ} \mathrm{C}$. A suspension of CRIB cells was added at the final of serum-virus incubation period and the plates were incubated at $37^{\circ} \mathrm{C}$ under a $5 \% \mathrm{CO}_{2}$ atmosphere for $72 \mathrm{~h}$. Test readings were performed and the virus titers were considered the reciprocal of the highest dilutions of sera capable of preventing the production of CPE. Geometric mean titers (G) were calculated according $G=2^{(\log x 1+\log \times 2+\ldots \log x n) / n}$ and only positive sera were included (Toma et al. 1999). Serum samples collected from vaccinated animals at different intervals were tested against the parental virus (SV507/99) and against several isolates of BoHV-1 (Cooper, SV56/90, EVI123 and SV371/05) and BoHV-5 (EVI88, SV136/88 and EVI340). Statistical analysis of the data was performed by analysis of variance and Tukey's test. Assays for anti-gE specific antibodies - the development of antibodies to glycoprotein $E$ by vaccinated animals was investigated by testing sera collected from both groups at day 78 pv using a commercial anti-BHV-1 gE blocking ELISA ${ }^{9}$ according to manufactures' recommendations.

\section{RESULTS}

Both viruses replicated to high titers in CRIB cell monolayers $\left(>10^{7.8} \mathrm{TCID}_{50} / \mathrm{ml}\right)$ and thus were suitable to formulate an inactivated vaccine. Virus inactivation using the BEI protocol was efficient, as residual virus or bacterial contamination were not detected in the vaccine formulation throughout the process. Vaccine administration was performed by the subcutaneous route in the lateral face of the right shoulder. No adverse reactions were noticed in the days following vaccination.

Serum samples were collected at different intervals after vaccination and submitted to $\mathrm{VN}$ tests using the parental (homologous BoHV-5) virus to evaluate the immunogenicity of both vaccine formulations. The serological VN response - as measured by VN titers - was similar in both groups throughout the serum collections; the differences eventually observed were not statistically significantly ( $p>0.05 \%$ ) (Fig.1). At $22 \mathrm{dpv}, 14$ animals in the SV507/99 group and 12 calves in the BoHV-5 gE/TK $\Delta$ group were serologically positive, and the highest titers were 8 and 16 for SV507/99 and BoHV-5 gE/TK $\Delta$, respectively (Table 1). After the second vaccine dose all animals seroconverted and remained positive until the last bleed. The maximum levels of neutralizing antibodies were detected at $56 \mathrm{dpv}$ in both groups (Fig.1). At this time, the VN titers ranged from 4 to 256 in the SV507/99 and from 2 to 128 in the BoHV-5 gE/TK $\Delta$ group. The VN levels at 78 dpv were still high and thereafter demonstrated a tendency to decrease, which was confirmed at $116 \mathrm{dpv}$. The mean neutralizing titers on the last bleed (116dpv) decreased approximately $1 \log _{2}$ (Table 1 ). These results demonstrated

\footnotetext{
${ }^{6}$ Invitrogen, 1600 Faraday Ave, Carlsbald, Ca, USA.

${ }^{7}$ Nutricell, Dimas de Toledo Piza 521, Campinas, SP, Brazil.

${ }^{8}$ Montanide ISA 206, Seppic Inc., 7 Franck Kupka Boulevard, Paris, France.

${ }^{9}$ IDEXX, One IDDEX Dr, Westbrook, Maine, USA
} 
Table 1. Distribution of virus neutralizing titers in groups of cattle vaccinated with an inactivated BoHV-5 wildtype (SV507/99) or BoHV-5 gE/TK $\Delta$ vaccine

\begin{tabular}{|c|c|c|c|c|c|c|c|c|}
\hline \multirow[b]{2}{*}{$\mathrm{DPV}^{\mathrm{a}}$} & \multicolumn{4}{|c|}{ SV507/99 vaccine } & \multicolumn{4}{|c|}{ BoHV-5 gE/TK $\Delta$ vaccine } \\
\hline & Reagents & $\begin{array}{l}\text { Lowest } \\
\text { titerb }\end{array}$ & $\begin{array}{c}\text { Highest } \\
\text { titer }^{b}\end{array}$ & $\mathrm{G}^{\mathrm{C}}$ & Reagents & $\begin{array}{c}\text { Lowest } \\
\text { titerb }^{b}\end{array}$ & $\begin{array}{l}\text { Highest } \\
\text { titer }^{\mathrm{b}}\end{array}$ & $\mathrm{G}^{\mathrm{C}}$ \\
\hline 0 & $0 \%$ & $\leq 2$ & $\leq 2$ & 0 & 0 & $\leq 2$ & $\leq 2$ & 0 \\
\hline 22 & $70 \%$ & $0(6)$ & $8(1)$ & 3.1 & $60 \%$ & $0(8)$ & $16(1)$ & 2.9 \\
\hline 56 & $100 \%$ & $4(2)$ & $256(1)$ & 17.5 & $100 \%$ & $2(1)$ & $128(1)$ & 24.1 \\
\hline 78 & $100 \%$ & $4(2)$ & $128(1)$ & 19.5 & $100 \%$ & $4(2)$ & $64(3)$ & 18.2 \\
\hline 116 & $100 \%$ & $2(2)$ & $32(1)$ & 7.4 & $100 \%$ & $2(4)$ & $64(1)$ & 6.3 \\
\hline
\end{tabular}

a dpv - days post-vaccination.

${ }^{b}$ VN - titer and bracketed number of animals reagents with indicated titer.

${ }^{c} \mathrm{G}$ - geometric mean titer of positive animals and calculated according to the method described in material and methods.

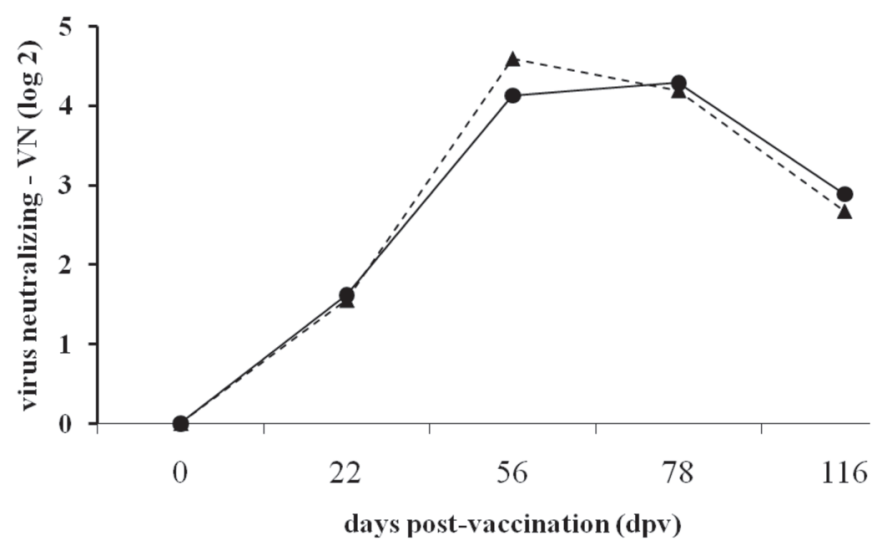

Fig.1. Immunogenicity of inactivated vaccines formulated with BoHV-5 SV507/99 (•) or BoHV-5 gE/TK $(\Delta)$. Virus neutralization titers are expressed as of geometric mean (G) calculated at different days post vaccination (dpv). The vaccines were administered at days 0 and 22pv.

that the deletion of $\mathrm{gE}$ and TK in the parental BoHV-5 had no adverse effects in the immunogenicity of the viral antigens, since both vaccine groups responded in a similar fashion. Nonetheless, the observed immune response was typical of an inactivated vaccine, in which a boost was necessary to induce an adequate response, and the magnitude of the immunity tended to decrease overtime.

Sera collected at $56 \mathrm{dpv}$ from both groups were tested by VN against heterologous isolates of BoHV-5 (EVI88, SV136/88 and EVI340) and BoHV-1 (Cooper strain, SV56/ 90, EVI123 and SV371/05). In general, the levels of serological cross-neutralization were similar when serum samples from both groups were tested against the same virus, either BoHV-5 or BoHV-1 (Fig. 2A and 2B). However, the neutralizing titers against BoHV- 5 isolates were superior to those to BoHV-1 isolates. These results clearly demonstrated high levels of cross-neutralization between BoHV-5 and BoHV-1, yet titers of higher magnitude were observed against BoHV-5 isolates.

In order to investigate whether the recombinant virus (BoHV-5 gE/TK $\Delta$ ) would induce a serological response differentiable from that induced by the whole virus, serum samples collected at $78 \mathrm{dpv}$ were tested by a commercial
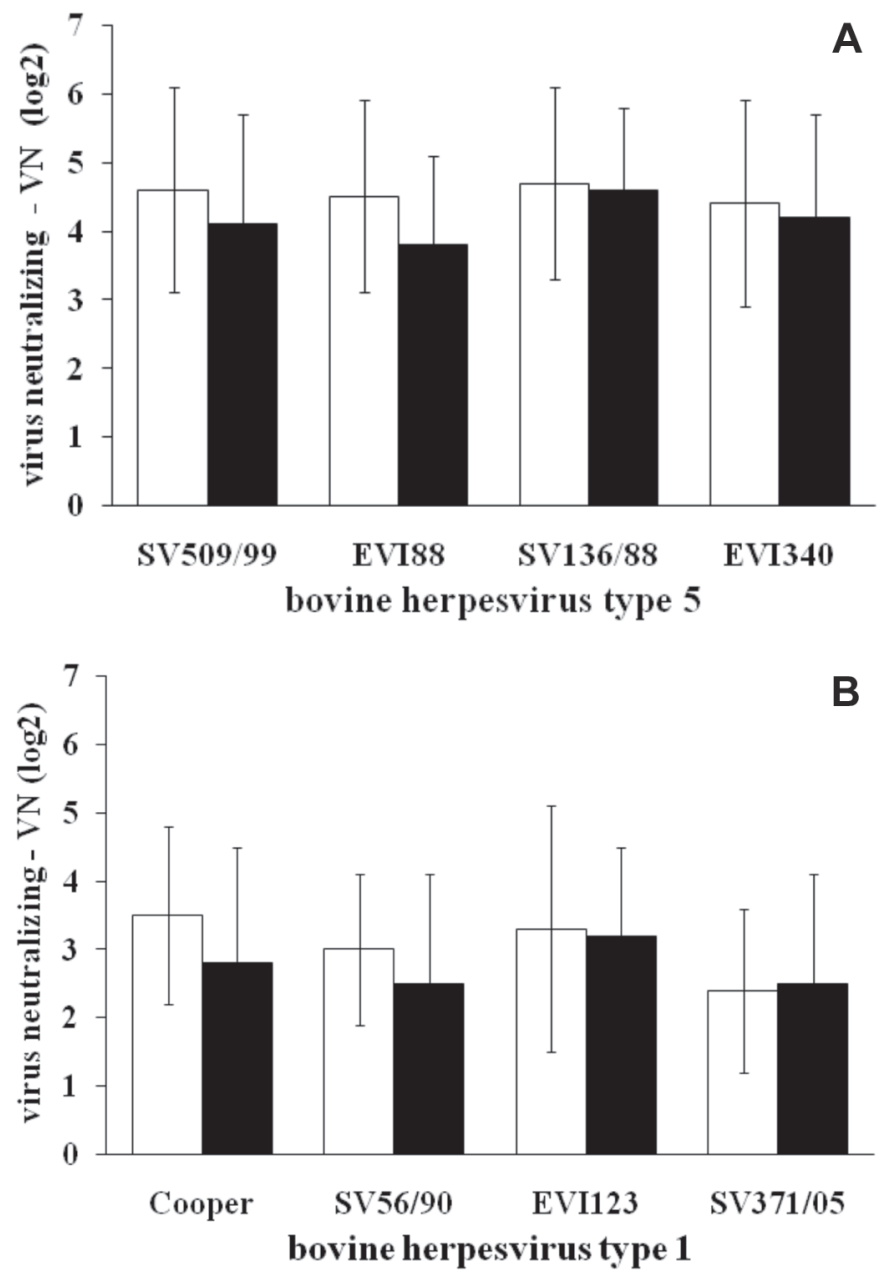

Fig.2. Cross-reactivity of serum samples collected at $56 \mathrm{dpv}$ (day post vaccination) from animals vaccinated with an inactivated BoHV-5 SV507/99 or BoHV-5 gE/TK $\Delta$-based vaccine. Columns demonstrate the geometric means of reagents animals and the standard deviation is indicated by error bars. (A) Cross serology of serum samples the against homologous (SV507/99) and different field isolates of BoHV5; (B) Cross serology of serum samples against the reference strain Cooper and field isolates of BoHV-1.

anti-BHV-1 gE ELISA. The results demonstrated that animals vaccinated with the recombinant BoHV- $5 \mathrm{gE} / \mathrm{TK} \Delta$ did not seroconvert to $\mathrm{gE}(0 / 20)$. Among the 20 calves immunized with antigens of the parental virus, three were frankly positive and two were suspicious in the gE ELISA. These results demonstrated that vaccination with BoHV-5 $\mathrm{gE} / \mathrm{TK}$ did not induce antibodies against $\mathrm{gE}$, and therefore can be used as an antigenically marker vaccine.

\section{DISCUSSION}

The immunogenicity and serological cross-neutralization of two inactivated BoHV- 5 based vaccines were evaluated. A recombinant BoHV-5 strain lacking the $\mathrm{gE}$ and TK genes was used to formulate an inactivated vaccine and the serological response induced by its antigens was compared to that induced by its parental virus SV507/99- 
based vaccine. The difference between the two viruses used is the absence of $\mathrm{gE}$ and TK genes, deleted from the parental virus by genetic manipulation (Brum et al. 2009). Both deleted genes are non essential for virus replication in cell culture and therefore can be deleted without affecting the capacity of the virus to replicate in tissue culture (Ackermann \& Engels 2006, van Drunen Littel van den Hurk 2007). The enzyme TK is a non-structural protein responsible for nucleotide phosphorylation in non-dividing cells such as neurons (Tikoo et al. 1995). Glycoprotein E $(\mathrm{gE})$ is a structural protein present in the viral envelope and has been shown to be immunogenic (Schwyzer \& Ackermann 1996, Ackermann \& Engels 2006). Both genes have been targets of choice for deletion towards virus attenuation and antigenic marking in BoHV-1 vaccines, respectively (Kaashoek et al. 1996).

Our results showed that the inactivated BoHV-5 gE/ $\mathrm{TK} \Delta$ strain retained its immunogenicity in similar levels to that of the parental strain, indicating that deletion of the gene coding for $\mathrm{gE}$ did not adversely affect the immune response induced by whole viral antigens. Seroconversion of all animals - in moderate to high neutralizing antibody titers - was achieved 30 days after the second vaccine dose. The levels of $\mathrm{VN}$ antibodies decreased progressively overtime, indicating the need of revaccination every six month or annually. The gradual reduction of $\mathrm{VN}$ titers and the need for periodic revaccination to maintain adequate levels of antibodies are typical of BoHV-1 inactivated vaccines (van Drunen Littel van den Hurk 2007).

Vaccination is the most cost-effective strategy to control BoHV-1 infection in the field and inactivated or modified live virus (MLV) vaccines are available (van Oirschot 1999, Ackermann \& Engels 2006). Based on biological properties, alphaherpesviruses are suitable for the development of DIVA vaccines, which can be used either as killed or live vaccines (van Oirschot et al. 1996). Due to cross reactivity between BoHV- 1 and -5 and the lack of specific BoHV- 5 vaccines, vaccination against BoHV-1 may be indicated to protect against BoHV-5 infection and disease (Cascio et al. 1999, Vogel et al. 2002, Del Medico Zajac et al. 2006). Cattle immunized with BoHV-1 and challenged with BoHV-5 showed a reduced virus shedding and were partially protected from clinical disease (Cascio et al. 1999, Del Medico Zajac et al. 2006, Silva et al. 2006). In the present study, the results of VN assays testing serum samples from both vaccine groups against different BoHV-5 and BoHV-1 isolates clearly demonstrated cross-reactivity between the two viruses. However, as may be expected, the levels of cross-reactivity were higher when serum samples were tested against BoHV5 isolates than against BoHV-1 isolates. The serological cross-reactivity between BoHV-1 and BoHV- 5 has also been demonstrated in other vaccine studies (Petzhold et al. 2001, Vogel et al. 2002, Silva et al. 2007a).

Some European countries successfully controlled and/ or eradicated BoHV-1 infection by the use of DIVA vaccines accompanied by serological tests able to differentiate between vaccinated and naturally infected animals (Ackermann \&
Engels 2006). BoHV-1 (and BoHV-5) vaccination is still insipient in most South American countries including Brazil and DIVA vaccines are not commercially available nowadays in the country (Silva et al. 2007a). Specific control of BoHV5 infections is restricted to farms where clinical cases had been diagnosed. In these cases, management measures and even vaccination with BoHV-1 vaccines have been recommended (Flores 1998). Thus, the development of an improved and specific BoHV-5 vaccine become necessary and several efforts to produce such vaccine have been conducted, including the early development of BoHV-5 vaccines (Halfen et al. 2000, Fischer et al. 2007, Franco et al. 2007). In this sense, the BoHV-5 strain lacking gE and TK used as inactivated vaccine may be an adequate alternative for the control of BoHV-5 infection and disease.

The knowledge of the immune response to BoHV-5 is basically limited to investigations of the humoral, virus neutralizing response after experimental infection or vaccination (Cascio et al. 1999, Vogel et al. 2003, Del Medico Zajac et al. 2006). Based on the genetic and biological similarities with BoHV-1, the immunological mechanisms underlying the host response to these two viruses should be likely very similar. Humoral and cellular immunity play an important role preventing and controlling BoHV-1 infection (Jones \& Chowdhury 2007, van Drunen Littel van den Hurk 2007), the same likely holds true for BoHV-5. Serum virusneutralizing (VN) titers have been considered the main immunological indicator to evaluate BoHV-1 vaccine potency (Ackermann \& Engels 2006). However, these parameters should not be used as the sole indicators of protection since no definitive correlation between $\mathrm{VN}$ titers and protection has been definitively established for this virus (Ackermann \& Engels 2006). Vaccination-challenge experiments are obviously needed as to ascertain the protection conferred by this experimental vaccine against the homologous (BoHV-5) and heterologous (BoHV-1) viruses.

The absence of specific anti-gE antibodies in the BoHV$5 \mathrm{gE} / \mathrm{TK} \Delta$ vaccine group demonstrated by testing sera with a commercial ELISA indicated the differential capacity of the vaccine virus. This was an expected finding since the recombinant BoHV-5 gE/TK was shown not to express $\mathrm{gE}$ in tissue culture (Brum et al. 2009). The relatively low percentage of $\mathrm{gE}$-positive and $\mathrm{gE}$-suspect animals in the BoHV-5 wt vaccine group could be attributed to a low immunogenicity of gE (Kaashoek et al. 1996), regimen of vaccination (only two doses), animals not challenged with live virus and the use of BoHV-1 antigen in the ELISA test. Usually, serological differentiation by glycoprotein-specific ELISAs is used to identify naturally infected animals that seroconverted to wildtype virus following a natural infection and to distinguish them from those vaccinated with a differential vaccine (van Oirschot 1999). Even though BoHV5 and BoHV-1 gE cross react serologically, a specific BoHV$5 \mathrm{gE}$ ELISA would be necessary to accompany the candidate BoHV-5 gE-deleted vaccine.

The main goal of the experiment presented herein was to demonstrate that under an inactivated vaccine 
formulation, the deleted virus BoHV-5 gE/TK $\Delta$ has similar immunogenicity to that of the parental strain in cattle, with the advantage of being potentially used as a differential vaccine. Our results showed that the recombinant virus retained its immunogenicity upon cattle immunization. Seroconversion in all animals was detected after the second vaccine dose. VN titers reached the maximum titer at $56 \mathrm{dpv}$ and maintained moderate levels up to day 112pv. In addition, cross-neutralization with different BoHV-5 isolates or heterologous BoHV-1 viruses indicated a broad reactivity. Finally, the capacity of serological differentiation would be a major advantage of BoHV-5 gE/TK strain to be used in future vaccine formulations.

\section{REFERENCES}

Ackermann M. \& Engels M. 2006. Pro and contra IBR-eradication. Vet. Microbiol. 113(3/4):293-302.

Bahnemann H.G. 1976. Inactivation of viruses in serum with binary ethyleneimine. J. Clin. Microbiol. 3:209-210.

Bratanich A.C., Sardi S.I., Smitsaart E.N. \& Schudel A.A. 1991. Comparative studies of BHV-1 variants by in vivo-in vitro tests. Zentralbl. Veterinärmed. B 38(1):41-48.

Brum M.C., Weiblen R., Flores E.F. \& Chowdhury S. 2009. Construction and in vitro growth properties of bovine herpesvirus type 5 recombinants defective in the glycoprotein $\mathrm{E}$, thymidine kinase and both genes. Braz. J. Med. Biol. Res. (Accepted for publication)

Cascio K.E., Belknap E.B., Schultheiss P.C., Ames A.D. \& Collins J.K. 1999. Encephalitis induced by bovine herpesvirus 5 and protection by prior vaccination or infection with bovine herpesvirus 1. J. Vet. Diagn. Invest. 11(2):134-139.

Del Medico Zajac M.P., Puntel M., Zamorano P.I., Sadir A.M. \& Romera S.A. 2006. BHV-1 vaccine induces cross-protection against BHV-5 disease in cattle. Res. Vet. Sci. 81(3):327-334.

Delhon G., Moraes M.P., Lu Z., Afonso C.L., Flores E.F., Weiblen R., Kutish G.F. \& Rock D.L. 2003. Genome of bovine herpesvirus 5. J. Virol. 77(19):10339-10347.

Engels M. \& Ackermann M. 1996. Pathogenesis of ruminant herpesvirus infections. Vet. Microbiol. 53(1/2):3-15.

Fischer G., Cleff M.B., Dummer L.A., Paulino N., Paulino A.S., de Oliveira Vilela C., Campos F.S., Storch T., D’Avila Vargas G., Hubner S. O. \& Vidor T. 2007. Adjuvant effect of green propolis on humoral immune response of bovines immunized with bovine herpesvirus type 5. Vet. Immunol. Immunopathol. 116(1/2):79-84.

Flores E.F. 1998. Comunicação pessoal (Universidade Federal de Santa Maria, Santa Maria, RS).

Flores E.F. \& Donis R.O. 1995. Isolation of a mutant MDBK cell line resistant to bovine viral diarrhea virus infection due to a block in viral entry. Virology 208(2):565-575

Flores E.F., Osorio F.A., Zanella E.L., Kit S. \& Kit M. 1993. Efficacy of a deletion mutant bovine herpesvirus-1 (BHV-1) vaccine that allows serologic differentiation of vaccinated from naturally infected animals. J. Vet. Diagn. Invest. 5(4):534-540.

Franco A.C., Rijsewijk F.A.M., Flores E.F., Weiblen R. \& Roehe P.M. 2002. Construction and characterization of a glycoprotein $E$ deletion mutant of bovine herpesvirus type 1.2 strain isolated in Brazil. Braz. J. Microbiol. 33(3):274-278.

Franco A.C., Hübner S.O., Oliveira A.P., Batista H.B.C.R., Roehe P.M. \& Rijsewijk F.A.M. 2007. Construction and characterization of a bovine herpesvirus 5 mutant with a deletion of the gl, gE and US9 genes. Braz. J. Microbiol. 38(4):667-673.

Halfen D.C., Vidor T., Braga F.M. \& van Der Laan C.W. 2000. Imunogenicidade do herpesvírus bovino tipo 5 (BHV-5) em vacinas inativadas de diferentes formulações. Ciência Rural 30(5):851-856.

Jones C. \& Chowdhury S. 2007. A review of the biology of bovine herpesvirus type $1(\mathrm{BHV}-1)$, its role as a cofactor in the bovine respiratory disease complex and development of improved vaccines. Anim. Health Res. Rev. 8(2):187-205.

Kaashoek M.J., Moerman A., Madic J., Weerdmeester K., Maris-Veldhuis M., Rijsewijk F.A. \& van Oirschot J.T. 1995. An inactivated vaccine based on a glycoprotein E-negative strain of bovine herpesvirus 1 induces protective immunity and allows serological differentiation. Vaccine 13(4):342-346.

Kaashoek M.J., van Engelenburg F.A., Moerman A., Gielkens A.L., Rijsewijk F.A. \& van Oirschot J.T. 1996. Virulence and immunogenicity in calves of thymidine kinase- and glycoprotein E-negative bovine herpesvirus 1 mutants. Vet. Microbiol. 48(1-2):143-153.

Lovato L., Inman M., Henderson G., Doster A. \& Jones C. 2003. Infection of cattle with a bovine herpesvirus 1 strain that contains a mutation in the latency-related gene leads to increased apoptosis in trigeminal ganglia during the transition from acute infection to latency. J. Virol. 77(8):4848-4857.

Petzhold S.A., Reckziegel P.E., Prado J.A.P., Teixeira J.C., Wald V.B., Esteves P.A., Spilki F.R. \& Roehe P.M. 2001. Neutralizing antibodies to bovine herpesviruses types 1 (BHV-1) and 5 (BHV-5) induced by an experimental, oil-adjuvanted, BHV-1 vaccine. Braz. J. Vet. Res. Anim. Sci. 38(4):184-187.

Roizman B., Desrosiers R.C., Fleckenstein B., Lopez C., Minson A.C. \& Studdert M.J. 1992. The family Herpesviridae: An update. The Herpesvirus Study Group of the International Committee on Taxonomy of Viruses. Arch. Virol. 123(3/4):425-449.

Schwyzer M. \& Ackermann M. 1996. Molecular virology of ruminant herpesviruses. Vet. Microbiol. 53(1-2):17-29.

Silva A.D., Spilki F.R., Franco A.C., Esteves P.A., Hubner S.O., Driemeier D., Oliveira A.P., Rijsewijk F. \& Roehe P.M. 2006. Vaccination with a gE-negative bovine herpesvirus type 1 vaccine confers insufficient protection to a bovine herpesvirus type 5 challenge. Vaccine 24(16): 3313-3320.

Silva L.F., Weiblen R. \& Flores E.F. 2007a. Imunogenicidade de vacinas comerciais inativadas contra o herpesvírus bovino tipo 1. Ciência Rural 37(5):1471-1474.

Silva M.S., Brum M.C.S., Weiblen R. \& Flores E.F. 2007b. Identificação e diferenciação de herpesvírus bovino tipos 1 e 5 isolados de amostras clínicas no Centro-Sul do Brasil, Argentina e Uruguai (1987-2006). Pesq. Vet. Bras. 27(10):403-408.

Strube W., Auer S., Block W., Heinen E., Kretzdorn D., Rodenbach C. \& Schmeer N. 1996. A gE deleted infectious bovine rhinotracheitis marker vaccine for use in improved bovine herpesvirus 1 control programs. Vet. Microbiol. 53(1/2):181-189.

Suarez-Heinlein A., Metzler A.E., Weiblen R., Berrios P., Schudel A.A. \& Rodriguez M. 1993. Molecular characterization of South American bovine herpesvirus-1 isolates with monoclonal antibodies and SDSPAGE. Zentralbl. Veterinarmed. B 40(2):125-130.

Tikoo S.K., Campos M. \& Babiuk L.A. 1995. Bovine herpesvirus 1 (BHV1): biology, pathogenesis, and control. Adv. Virus Res. 45:191-223.

Toma B., Vaillancout J.P., Dufour B., Eloit M.G., Marsh W., Bénet J.J., Sanaa M. \& Michel P. 1999. Dictionary of Veterinary Epidemiology. lowa State Universtiy Press, Ames, p.122-134.

van Drunen Littel-van den Hurk S. 2007. Cell-mediated immune responses induced by BHV-1: Rational vaccine design. Expert. Rev. Vaccines 6(3):369-380.

van Oirschot J.T. 1999. Diva vaccines that reduce virus transmission. J. Biotechnol. 73(2-3):195-205.

van Oirschot J.T., Kaashoek M.J. \& Rijsewijk F.A. 1996. Advances in the development and evaluation of bovine herpesvirus 1 vaccines. Vet. Microbiol. 53(1/2):43-54.

Vogel F.S.F., Flores E.F., Weiblen R. \& Kunrath C.F. 2002. Atividade neutralizante anti-herpesvírus bovino tipos 1 (BHV-1) e 5 (BHV-5) no soro de bovinos imunizados com vacinas contra o BHV-1. Ciência Rural 32(5):881-883.

Vogel F.S.F., Caron L., Flores E.F., Weiblen R., Winkelmann E.R., Mayer S.V. \& Bastos R.G. 2003. Distribution of bovine herpesvirus type 5 DNA in the central nervous systems of latently, experimentally infected calves. J. Clin. Microbiol. 41(10):4512-4520. 